\title{
AC 2012-3538: PERCEIVED LEVELS OF FACULTY VALUE, INFLUENCE, AND SATISFACTION BY GENDER, RANK, ETHNICITY, COLLEGE, AND DEPARTMENT AT A LARGE PRIVATE UNIVERSITY
}

Prof. Carol E. Marchetti, Rochester Institute of Technology

Carol Marchetti received her B.S. in mathematics and M.S. in operations research from Case Western Reserve University, and a Ph.D. in statistics from the University of Rochester. Her experience includes teaching introductory and advanced undergraduate statistics courses at Rochester Institute of Technology. She is currently an Associate Professor in the School of Mathematical Sciences at RIT. Her research interests include statistics education, collaborative learning, deaf education, and online learning.

\section{Prof. Margaret B. Bailey, Rochester Institute of Technology}

Margaret B. Bailey, P.E., is a professor of mechanical engineering within the Kate Gleason College of Engineering at the Rochester Institute of Technology (RIT) located in Rochester, N.Y. Bailey is also the Founding Executive Director for the nationally recognized women in engineering program called WE@RIT (http://we.rit.edu/). At the institute level, Bailey serves as Faculty Associate to the Provost for female faculty and she co-chairs the President's Commission on Women. In these roles, she leads efforts to create strategies to increase the representation of women undergraduate students and improve recruitment, retention, and advancement of women faculty. Within her college, Bailey teaches energy-related courses and serves as a mentor and advisor to undergraduate and graduate mechanical engineering students who are involved in her research. Bailey teaches courses related to thermodynamics, engineering and public policy, and design. She is actively involved in curricular development and assessment activities, ranging from individual courses to college and institute-wide programs. Bailey and her graduate students conduct research in thermodynamic analyses of complex, energy-intensive systems such as coal-fired power plants and commercial refrigeration plants.

\section{Prof. Stefi Alison Baum, Rochester Institute of Technology}

Carlson Center for Imaging Science

Prof. Sharon Patricia Mason, Rochester Institute of Technology

Prof. Maureen S. Valentine, Rochester Institute of Technology

Maureen Valentine, P.E., has been a faculty member at RIT for more than 19 years and held the position of Department Chair for the Department of Civil Engineering Technology, Environmental Management, and Safety from 2000 to 2008. She is currently the Associate Dean of the College of Applied Science and Technology. Her scholarly activities recently have focused on women in technology programs and the female faculty who teach them.

(C)American Society for Engineering Education, 2012 


\title{
Perceived Levels of Faculty Value, Influence, and Satisfaction by Gender, Rank, Ethnicity, College, and Department at a Large Private University
}

\begin{abstract}
The ADVANCE IT-Catalyst project, "Establishing the Foundation for Future Organizational Reform and Transformation at Rochester Institute of Technology" (EFFORT@RIT) was a multiyear study conducted from 2008-2010 across six colleges which include Science, Technology, Engineering and Mathematics (STEM) disciplines. The overarching project mission is to increase the representation and advancement of women STEM faculty. In order to achieve this mission, the project goal was to develop an evidence-based approach to address factors resulting in the under-representation of women in STEM faculty positions. The research objective was to identify barriers for current female RIT STEM faculty in regards to rank, tenure, leadership role progression, and resource allocation in order to establish how well the university addresses issues that have been found to be important in the recruitment, retention, and advancement of women faculty. In year two of the study, a university-wide faculty work-life survey was administered with response rates exceeding $70 \%$ of the tenured and tenure track faculty in each of the primary STEM colleges. During year three of the study, the survey results were analyzed to examine how gender, ethnicity, and faculty perception of value and influence are associated with reported overall satisfaction with one's position at the university.
\end{abstract}

This paper is the second in a series that examines data from this study. Paper 1 [1] reported on the distribution of RIT STEM faculty, outcomes of institutional processes of recruitment and advancement, distribution of STEM faculty in leadership positions, allocation of resources for STEM faculty, barriers to the recruitment and advancement of women, success of existing structures at addressing these barriers, accomplishments over the grant period, and plans for institutionalizing various initiatives. This paper focuses on distillation of climate survey data to obtain useful and meaningful measures related to work/life balance, climate, value and influence. The paper also explores answers to the following research questions in the context of RIT: Which factors best explain reported overall faculty satisfaction with one's position at the university? How is satisfaction related to faculty perception of value and influence? Are there differences in perceived value and influence by variables such as gender or ethnicity? Dissemination strategy is discussed as well as how answers to these and other related research questions support and inform the creation of a large institutional transformation strategy for RIT.

\section{Background}

In 2010, RIT employed 95 women as tenured and tenure-track (T TT) faculty in the science, technology, engineering, and mathematics (STEM) disciplines, or $22.8 \%$ of the total STEM T TT faculty; this is significantly below the $34 \%$ average of doctoral scientists and engineers employed at Master's granting colleges and universities in the U.S. [2]. A comparison (Table 1) of RIT's women faculty representation to the percentage of doctorates awarded to women nationally [2] reveals fewer women except for the computer science category, in which a high percentage of RIT women T TT faculty within the College of Computing and Information Sciences have master's degrees as their highest degree (a relic of past hiring practices). The number of STEM T TT women faculty at RIT has nearly tripled in the past 15 years as the size of the STEM faculty has more than doubled, therefore the representation of women STEM T TT faculty has increased slowly from $15.9 \%$ in 1995 to $22.8 \%$ in 2010 . In addition, there is wide variability in the representation of women faculty members between STEM departments even within the same 
college. For example in October 2010, within the College of Science there was a large disparity between the percentage of women faculty within life and physical sciences with representations of $43 \%$ (15/35) and 13\% (5/39), respectively. Both representations are significantly below national availability and the gap between the values is larger than expected based on the national trends [3]. In addition there were five academic STEM units at RIT in October 2010 with no female T TT faculty.

Table 1. Comparison of RIT Women T TT Faculty with National Availability*

\begin{tabular}{|l|c|c|}
\hline & RIT \% Women (2010) & National \% Women \\
\hline Engineering (not Engr. Tech.) & $12 \%$ & $21.6 \%$ \\
\hline Physical Sciences & $13 \%$ & $29.3 \%$ \\
\hline Computer Sciences & $29 \%$ & $22.0 \%$ \\
\hline Mathematics and Statistics & $16 \%$ & $31.1 \%$ \\
\hline Biological Sciences & $43 \%$ & $50.6 \%$ \\
\hline Psychology & $40 \%$ & $72.0 \%$ \\
\hline Social Sciences & $36 \%$ & $48.6 \%$ \\
\hline
\end{tabular}

*Based on the percentage of doctorates awarded to women nationally [2]

This data indicates that RIT has faced some challenges in recruiting female STEM faculty. Importantly, the EFFORT@RIT project identified the following major barriers to the recruitment and advancement of women STEM faculty at RIT; career navigation, climate, and flexibility/options for managing the work/life balance. To quote from Paper I [1]:

"Issues related to career navigation could be caused by women's self-agency and negotiation skills, coupled with a lack of "sponsorship" from more seasoned faculty and/or administration, hinder the success of female faculty in obtaining more advantageous starting packages, assignments, compensation, and promotion. Climate issues are exacerbated by women's view of the workplace in personal terms, as opposed to a more male process-oriented view, meaning that issues of connectedness, support, and interpersonal relations, are important to their success... Finally, managing work/life balance through flexible work arrangements, available and convenient child care, and tenure clock adjustments, may lower stress and increase satisfaction, and potentially aid in the retention of female (and male) faculty."

In addition to recruitment challenges, retention data is equally important to consider in the overall representation of women faculty. It has been shown that women faculty leave institutions of higher learning at a higher rate than men $[1,4,5,6]$. However, why they leave is not well established. At Penn State University, faculty exit data indicate the greatest dissatisfaction with rewards for teaching/outreach and the validity of performance evaluation methods [7]. Several studies have found gender differences in satisfaction, with female faculty less satisfied than their male counterparts $[1,7,8,9,10]$ and assistant professors less satisfied than professors $[1,7,9]$. Some of the reasons put forth to explain these differences include clarity around promotion policies, practices that support work-life balance [10], sense of belonging [8] and guidance and appreciation by colleagues $[10,11]$ and upper administration $[9,12]$.

To learn more about the recruitment and retention of women faculty at RIT, the EFFORT research team developed a climate survey, using prior ADVANCE climate surveys as a guide. This survey was shaped by preliminary findings at RIT and supported by the literature. The survey was administered at RIT in the fall of 2009. 


\section{Methodology}

Over the course of the 2008 academic year, the project research team developed a comprehensive career-life survey focusing on gender issues in STEM. The team reviewed climate surveys previously developed and administered at other NSF ADVANCE institutions, primarily the survey developed at the University of Michigan [13] and the University of Wisconsin-Madison [14]. Questions from these surveys were adapted to meet the specific needs of the RIT environment. Additional questions were composed based on existing RIT culture and background. The survey was structured around four primary areas:

- Teaching, Resources, and Service

- Career Satisfaction, Work Load, Recognition

- Climate, Mentoring, Tenure, Promotion

- Balancing Personal and Professional Life

Four individuals with experience in assessment and evaluation, but not involved in this study as investigators or survey participants, tested the final survey instrument in a paper format for clarity of questions and categories, formatting and time requirements. Minor updates were made based on their feedback. The Survey Research Institute (SRI) at Cornell University [15] then coded the instrument to be offered to all tenure and tenure-track faculty at RIT via a secure website. The survey titled the "RIT Faculty Career Life Survey" was administered at RIT in the fall of 2009. To ensure confidentiality, SRI directly invited participation of RIT faculty by sending all email on behalf of the RIT administration (invitation plan included as Table 2), tracking respondents, communicating with non-respondents and collecting and aggregating data. Overall, more than $66 \%$ of all tenured and tenure-track faculty at RIT completed the survey (Table 3 ). To download the full RIT Career Life Survey, visit http://nsfadvance.rit.edu/.

The climate survey included questions regarding the level of overall satisfaction with current position and serious consideration of leaving RIT, using a Likert scale response. Response patterns for these questions were explored by demographics using ordinal logistic regression. To explain overall satisfaction with current position and serious consideration of leaving RIT in terms of the climate survey questions, measures of Value \& Influence, Department Climate, and Work/Life Stress were created. Linear regression analyses were conducted using these measures as explanatory variables.

Table 2. Survey Invitation Plan

\begin{tabular}{|l|l|l|}
\hline Email Correspondence & Sent by & Date \\
\hline Invitation email from University President and Provost & SRI & OCT 1, 2009 \\
\hline First reminder email to non-respondents from President and Provost & SRI & Oct 14, 2009 \\
\hline Second reminder email to non-respondents from Provost & SRI & Oct 21, 2009 \\
\hline Third reminder email to non-respondents from Research Team & SRI & Oct 28, 2009 \\
\hline $\begin{array}{l}\text { Fourth (final) reminder email to non-respondents from Research } \\
\text { Team (indicating close date) }\end{array}$ & SRI & Nov 4, 2009 \\
\hline
\end{tabular}

Table 3. Survey Response Rates by Gender and College

\begin{tabular}{|c|c|c|c|}
\hline Gender & Completions & Out of & Rate \\
\hline Female & 175 & 245 & $71.43 \%$ \\
\hline Male & 360 & 563 & $63.94 \%$ \\
\hline Overall & $\mathbf{5 3 5}$ & $\mathbf{8 0 8}$ & $\mathbf{6 6 . 2 9 \%}$ \\
\hline
\end{tabular}




\begin{tabular}{|l|c|c|c|}
\hline College/Division & Completions & Out of & Rate \\
\hline Center for Integrated Manufacturing Studies & 3 & 6 & $50.00 \%$ \\
\hline College of Applied Science and Technology & 56 & 71 & $78.87 \%$ \\
\hline College of Imaging Arts and Sciences & 55 & 100 & $55.00 \%$ \\
\hline College of Liberal Arts & 83 & 124 & $66.94 \%$ \\
\hline College of Science & 99 & 137 & $72.26 \%$ \\
\hline E. Philip Saunders College of Business & 18 & 38 & $47.37 \%$ \\
\hline Golisano College of Computing \& Info Sciences & 68 & 92 & $73.91 \%$ \\
\hline Kate Gleason College of Engineering & 62 & 85 & $72.94 \%$ \\
\hline National Technical Institute for the Deaf & 87 & 147 & $59.18 \%$ \\
\hline Office of the President & 1 & 1 & $100.00 \%$ \\
\hline Provost & 3 & 6 & $50.00 \%$ \\
\hline Student Affairs & 0 & 1 & $0.00 \%$ \\
\hline Overall & $\mathbf{5 3 5}$ & $\mathbf{8 0 8}$ & $\mathbf{6 6 . 2 9} \%$ \\
\hline
\end{tabular}

\section{Results}

The survey results indicate differences in overall satisfaction with position (survey question 19k: All things considered, how satisfied are you with your current position at RIT?) by several demographic variables including gender, faculty rank, and STEM/non-STEM designation. In an ordinal logistic regression model of these variables on overall satisfaction, the following results were noted, where $\mathrm{p}$ represents the $\mathrm{p}$-value of the statistical test:

- All three demographic variables, namely gender, faculty rank, and STEM/non-STEM were significant.

- Higher satisfaction is more likely for males than for females $(\mathrm{p}<0.05)$.

○ $57 \%$ of females and $64 \%$ of males were satisfied.

- $21 \%$ of females and $16 \%$ of males were dissatisfied.

- Higher satisfaction is more likely for Professors than for Assistant Professors $(\mathrm{p}<0.01)$.

- No difference between Associate and Assistant Professors.

- Higher satisfaction is less likely for STEM faculty than for non-STEM $(p<0.01)$.

Overall, differences in average satisfaction (where $1=$ Very Dissatisfied and $5=$ Very Satisfied) align with the results of the regression. For example:

- Average Satisfaction by Gender: Female - 3.49, Male - 3.69

- Average Satisfaction by Rank: Assistant - 3.49, Associate - 3.49, Full - 3.90

- Average Satisfaction by STEM/non-STEM: STEM - 3.53, non-STEM - 3.75

Looking at the data further, it seems that gender differences in average satisfaction seem to grow with rank (faster for non-STEM than for STEM).

- Assistant and non-STEM: Female - 3.50, Male - 3.54 ( $\mathrm{F}-\mathrm{M}=-0.04)$

- Assistant and STEM: Female - 3.44, Male - 3.47 ( $\mathrm{F}-\mathrm{M}=-0.04)$

- Associate and non-STEM: Female - 3.52, Male - 3.69 (F- M = -0.17)

- Associate and STEM: Female - 3.26, Male - $3.41(\mathrm{~F}-\mathrm{M}=-0.15)$

- Full and non-STEM: Female - 3.75, Male - 4.29 ( $\mathrm{F}-\mathrm{M}=-0.54)$

- Full and STEM: Female - 3.47, Male - 3.80 ( $\mathrm{F}-\mathrm{M}=-0.33$ )

Female/male comparisons within rank and STEM/non-STEM do not show significance (except for non-STEM Full Professor), which could be due to the smaller sample sizes for the comparisons. 
A different measure related to satisfaction is consideration of leaving RIT. There were no significant differences in survey responses to the question regarding serious consideration of leaving RIT by demographic variables (survey question 36b: I have seriously considered leaving RIT in order to achieve better balance between work and personal life.) Overall, 25\% of faculty agree or strongly agree with this question.

To explain overall satisfaction with current position and serious consideration of leaving RIT in terms of the climate survey questions, measures of Value \& Influence, Department Climate, and Work/Life Stress were considered. Figure 1 summarizes these results, with plus signs on the arrows indicating positive relationships and minus signs indicating negative relationships.

For the analysis of each set of questions that follow, only respondents who answered all the questions in that set are included. The following seven variables were considered measures of Value \& Influence (with an alpha reliability coefficient of 0.75 ).

- Sense of being valued by unit/department and upper administration.

- Level of social interaction with colleagues, solicitation of opinions about scholarship.

- Satisfaction that one's research is on track for career advancement and with one's long range career plan.

- Amount of influence in the unit/department over obtaining a desired teaching schedule. A linear regression analysis of overall satisfaction on this set of variables termed Value \& Influence had an adjusted- $\mathrm{R}^{2}$ value of $60.3 \%$ (separately by gender, this is $58.2 \%$ for females and $61.4 \%$ for males). A linear regression of serious consideration of leaving RIT on these variables had an adjusted- $\mathrm{R}^{2}$ value of $12.1 \%$ ( $16.2 \%$ for females and $10.2 \%$ for males).

Department Climate was measured with a set of eight variables, including sociability, diversity, respect, collegiality, gender equality, collaboration, cooperation, and support (with an alpha reliability coefficient of 0.90 ). The linear regression of overall satisfaction on these Department Climate variables had an adjusted- $\mathrm{R}^{2}$ value of $20.8 \%$ (separately by gender, this is $19.2 \%$ for females and $21.3 \%$ for males). The linear regression of serious consideration of leaving RIT on these variables had an adjusted- $\mathrm{R}^{2}$ value of $9.2 \%$ (11.9\% for females and $8.6 \%$ for males).

Work/Life Stress was measured by satisfaction with the work/life balance and six sources of stress, including managing household responsibilities, child care issues, personal health, health of family members, personal finances, and planning for retirement (with an alpha reliability coefficient of 0.77 ).

- The Work/Life Stress set of variables was reliable for male faculty (alpha $=0.82)$ but not for female faculty (alpha $=0.60$ ). So for females, this set was reduced to only satisfaction with the work/life balance and stresses due to managing household responsibilities and child care issues (alpha $=0.77$ ).

- The linear regression of overall satisfaction on the entire set of Work/Life Stress variables had an adjusted- $\mathrm{R}^{2}$ value of $13.1 \%$ (and $17.2 \%$ for males), while the linear regression of serious consideration of leaving RIT on these variables had an adjusted- $\mathrm{R}^{2}$ value of $9.2 \%$ (16.4\% for males).

- The linear regression of overall satisfaction on the subset of work/life stress variables had an adjusted- $\mathrm{R}^{2}$ value of $7.3 \%$ for females, and the linear regression of serious consideration of leaving RIT had an adjusted- $\mathrm{R}^{2}$ value of $15.5 \%$ for females.

It appears that, for males, household responsibilities and child care are just as reliable as health and finance concerns in measuring stress. Female stress seems to be focused on household responsibilities and child care, while male sources of stress also include health and finance 
Figure 1. Regression Analyses for Satisfaction and Serious Consideration of Leaving

\begin{tabular}{|c|c|c|}
\hline \multirow{6}{*}{$\begin{array}{l}\text { Value \& Influence Factors } \\
\text { (alpha = 0.75): } \\
\text { - } \quad \text { Sense of being valued by } \\
\text { unit/department and upper } \\
\text { administration. } \\
\text { - Level of social interaction with } \\
\text { colleagues, solicitation of opinions } \\
\text { about scholarship. } \\
\text { Satisfaction that one's research is on } \\
\text { track for career advancement and with } \\
\text { one's long range career plan. } \\
\text { Amount of influence in the } \\
\text { unit/department over obtaining a } \\
\text { desired teaching schedule. } \\
\text { (alpha = } 0.73 \text { for women, } 0.76 \text { for men) }\end{array}$} & & \\
\hline & +All Faculty $\left(\mathrm{p}<0.0001\right.$, Adj-R $\left.\mathrm{R}^{2}=60.3 \%\right)$ & \multirow{3}{*}{$\begin{array}{l}\text { Overall } \\
\text { Satisfaction } \\
\text { with Position }\end{array}$} \\
\hline & + Women $\left(\mathrm{p}<0.0001\right.$, Adj- $\left.\mathrm{R}^{2}=58.2 \%\right)$ & \\
\hline & +Men $\left(\mathrm{p}<0.0001\right.$, Adj-R $\left.{ }^{2}=61.4 \%\right)$ & \\
\hline & - All Faculty $(\mathrm{p}<0.0001)$, Adj-R $\left.{ }^{2}=12.1 \%\right)$ & \multirow{2}{*}{$\begin{array}{l}\text { Seriously } \\
\text { Considered } \\
\text { Leaving RIT }\end{array}$} \\
\hline & \multirow{2}{*}{$\begin{array}{l}\text {-Men }\left(\mathrm{p}<0.0001, \text { Adj- } \mathrm{R}^{2}=10.2 \%\right) \\
+ \text { All Faculty }\left(\mathrm{p}<0.0001, \text { Adj- } \mathrm{R}^{2}=20.8 \%\right)\end{array}$} & \\
\hline \multirow{4}{*}{$\begin{array}{l}\text { Department Climate Factors } \\
\text { (alpha }=\mathbf{0 . 9 0}) \text { : } \\
\text { - } \quad \text { Sociability } \\
\text { - } \quad \text { Diversity } \\
\text { - } \quad \text { Respect } \\
\text { - } \quad \text { Collegiality } \\
\text { - } \quad \text { Gender Equality } \\
\text { - } \quad \text { Collaboration } \\
\text { - } \quad \text { Cooperation } \\
\text { - } \quad \text { Support } \\
\text { (alpha }=0.93 \text { for women, } 0.89 \text { for men) }\end{array}$} & & \multirow{2}{*}{$\begin{array}{l}\text { Overall } \\
\text { Satisfaction } \\
\text { with Position }\end{array}$} \\
\hline & $\begin{array}{l}+ \text { Women }\left(\mathrm{p}<0.0001, \text { Adj- } \mathrm{R}^{2}=19.2 \%\right) \\
+ \text { Men }\left(\mathrm{p}<0.0001, \text { Adj-R }-\mathrm{R}^{2}=21.3 \%\right)\end{array}$ & \\
\hline & - All Faculty $\left(\mathrm{p}<0.0001\right.$, Adj-R $\left.{ }^{2}=9.2 \%\right)$ & \multirow{2}{*}{$\begin{array}{l}\text { Seriously } \\
\text { Considered } \\
\text { Leaving RIT }\end{array}$} \\
\hline & & \\
\hline \multirow{2}{*}{$\begin{array}{l}\text { Work/Life Stress Factors }(\text { alpha }=\mathbf{0 . 7 7}) \text { : } \\
\text { - } \quad \text { Satisfaction with the work/life balance } \\
\text { - } \quad \text { Low stress levels due to } \\
\text { ○ Managing household } \\
\text { responsibilities }\end{array}$} & $\begin{array}{l}- \text { Women }\left(\mathrm{p}<0.0001, \text { Adj- } \mathrm{R}^{2}=11.9 \%\right) \\
- \text { Men }\left(\mathrm{p}<0.0001, \text { Adj- } \mathrm{R}^{2}=8.6 \%\right) \\
+ \text { All Faculty }\left(\mathrm{p}<0.0001, \text { Adj- } \mathrm{R}^{2}=13.1 \%\right)\end{array}$ & \multirow{2}{*}{$\begin{array}{l}\text { Overall } \\
\text { Satisfaction } \\
\text { with Position }\end{array}$} \\
\hline & + Men $\left(p<0.0001\right.$, Adj- $\left.R^{2}=17.2 \%\right)$ & \\
\hline ○ Child care issues & -All Faculty $\left(\mathrm{p}<0.0001\right.$, Adj-R $\left.{ }^{2}=9.2 \%\right)$ & \multirow{2}{*}{$\begin{array}{l}\text { Seriously } \\
\text { Considered } \\
\text { Leaving RIT }\end{array}$} \\
\hline $\begin{array}{ll}\circ & \text { Health of family members } \\
\circ & \text { Personal finances }\end{array}$ & \multirow[t]{2}{*}{- Men $\left(\mathrm{p}<0.0001\right.$, Adj-R $\left.{ }^{2}=16.4 \%\right)$} & \\
\hline $\begin{array}{c}\circ \quad \text { Planning for retirement } \\
(\text { alpha }=0.60 \text { for women, } 0.82 \text { for men) }\end{array}$ & & \\
\hline \multirow{2}{*}{$\begin{array}{l}\text { Subset of Work/Life Stress Factors for } \\
\text { Women Only (alpha =0.77): } \\
\text { - } \quad \text { Satisfaction with the work/life balance } \\
\text { - } \quad \text { Low stress levels due to }\end{array}$} & + Women $\left(\mathrm{p}<0.05\right.$, Adj- $\left.\mathrm{R}^{2}=7.3 \%\right)$ & \multirow{2}{*}{$\begin{array}{l}\text { Overall } \\
\text { Satisfaction } \\
\text { with Position }\end{array}$} \\
\hline & & \\
\hline $\begin{array}{l}\text { Managing household } \\
\text { responsibilities }\end{array}$ & - Women $(\mathrm{p}<0.05$, Adj & \multirow{2}{*}{$\begin{array}{l}\text { Seriously } \\
\text { Considered } \\
\text { Leaving RIT }\end{array}$} \\
\hline ○ Child care issues & & \\
\hline
\end{tabular}

concerns. However, satisfaction with the work/life balance has the strongest correlation with overall satisfaction and serious consideration of leaving (this is true for both males and females). Therefore, in explaining overall satisfaction with current faculty position at RIT in terms of the climate survey questions, the measure of Value \& Influence is the most useful with an adjusted- $\mathrm{R}^{2}$ 
value of $60.3 \%$. This measure is equally valid for men and women. Serious consideration of leaving RIT is not as well explained by any of the three measures.

In benchmarking these results to other universities it is clear that RIT is unique in the factors that predict faculty satisfaction with one's position.

- Harvard University found the extent to which department is a good fit (tenured faculty) and adequate overall mentoring (tenure-track faculty) to be the most significant positive contributors to job satisfaction [16].

- University of Michigan found the following factors to contribute positively to job satisfaction for STEM faculty: Satisfaction with resources, rating of chair, and the degree to which people feel that they influence department climate (men and women); positive climate (women); committee service (men) and gender egalitarian atmosphere (men). Factors contributing negatively to job satisfaction: Scholarly isolation (men and women); department failing to nominate them for an award (women); overhearing disparaging comments about women (women); and overhearing disparaging comments about racialethnic minorities (men) [13].

- Case Western Reserve University found that women seem to gain greater job satisfaction than men from a positive internal work environment while men seem to gain greater job satisfaction than women from internal academic resources [17].

Each set of questions used in the linear regression analyses was examined further. To reduce the number of variables, composite scores were created regarding faculty perceptions of Value \& Influence, Department Climate, and Work/Life Stress. Each individual response was standardized (represents a number of standard deviations above or below the average response to that question). A respondent's composite score is the average of their standardized responses to the questions in the set (a score can only be determined for respondents who answered all of the questions in a set).

Distributions of composite scores are displayed graphically in Figures 2 - 4 using boxplots. The left end of each box represents the $25^{\text {th }}$ percentile, the right end of the box represents the $75^{\text {th }}$ percentile, and the vertical line inside the box represents the median. Whiskers extending from the box denote the lowest and highest scores that are not outliers, and asterisks indicate outliers (more than $1.5^{*}$ [width of the box] from either end of the box). Scores were also analyzed by gender using two-sample t-tests. Composite scores have been analyzed by gender, ethnicity, and college. To maintain confidentiality, data was provided by SRI only where $n>5$ for the smallest subgroups within the data. For this reason, analyses could not be performed on all three variables at once. Figures 2 - 4 show the distributions of composite scores by gender and ethnicity, and Table 4 summarizes the average scores. The AALANA category includes African American, Latin American, and Native American faculty.

Table 4. Composite Scores by Gender and Ethnicity

\begin{tabular}{|l|c|c|c|c|c|c|}
\cline { 2 - 7 } \multicolumn{1}{c|}{ Cell Contents: Mean } & \multicolumn{2}{c|}{ AALANA } & \multicolumn{2}{c|}{ Asian } & \multicolumn{2}{c|}{ White } \\
\cline { 2 - 7 } & Female & Male & Female & Male & Female & Male \\
\hline Value \& Influence Composite & -0.361 & -0.280 & 0.225 & 0.020 & -0.112 & 0.035 \\
Score & $(13)$ & $(22)$ & $(7)$ & $(27)$ & $(110)$ & $(193)$ \\
\hline Department Climate Composite & -0.177 & -0.076 & -0.166 & -0.042 & -0.138 & 0.079 \\
Score & $(17)$ & $(26)$ & $(9)$ & $(33)$ & $(146)$ & $(283)$ \\
\hline Work/Life Stress Composite & -0.274 & -0.205 & -0.261 & 0.320 & -0.393 & 0.142 \\
Score & $(12)$ & $(22)$ & $(7)$ & $(23)$ & $(79)$ & $(172)$ \\
\hline
\end{tabular}


Figure 2. Distributions of Value \& Influence Composite Scores by Ethnicity and Gender (higher score $=$ higher perceived value $\&$ influence)

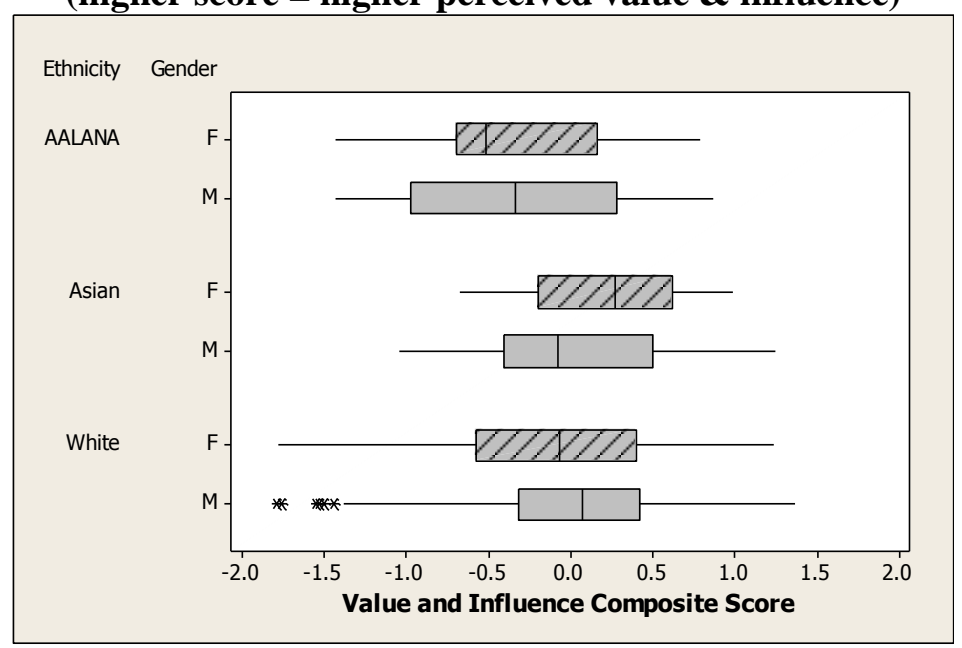

Figure 3. Distributions of Department Climate Composite Scores by Ethnicity and Gender (higher score $=$ more positive perception of department climate)

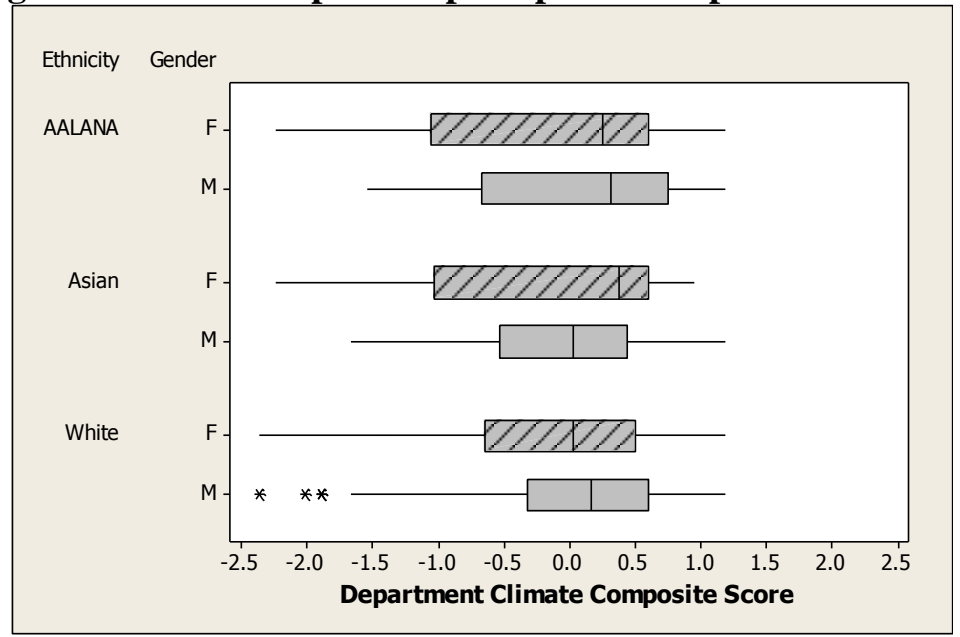

Figure 4. Distributions of Work/Life Stress Composite Scores by Ethnicity and Gender (higher score $=$ lower reported level of stress)

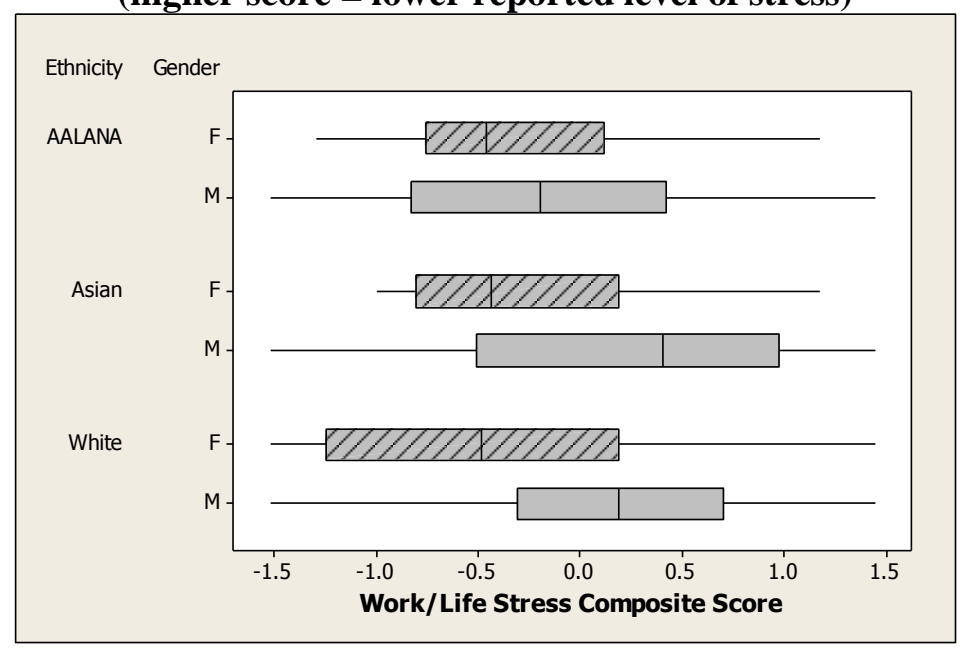


Scores were analyzed using two-way ANOVA. No significant interaction effects were present, however the following results were discovered:

- Differences in mean Value \& Influence composite score are significant by Ethnicity $(\mathrm{p}<0.05)$, but not by Gender. Specifically, the mean for AALANA respondents is significantly lower than the mean for White respondents as shown in Figure 5. Due to the small number of Asian respondents, the confidence interval for the Asian mean is very wide and overlaps with the confidence for the AALANA mean. Hence, these means are not significantly different.

- Differences in mean Department Climate composite score are significant by Gender $(\mathrm{p}<0.01)$, but not by Ethnicity. Specifically, the mean for Female respondents is significantly lower than the mean for Male respondents as shown in Figure 6.

- Differences in mean Work/Life Stress score are significant by Gender $(\mathrm{p}<0.0001)$, but not by Ethnicity. Specifically, the mean for Female respondents is significantly lower (indicating higher stress) than the mean for Male respondents, as shown in Figure 7.

Figure 5. Value \& Influence Composite Score by Gender and Ethnicity (higher score $=$ higher perceived value $\&$ influence)

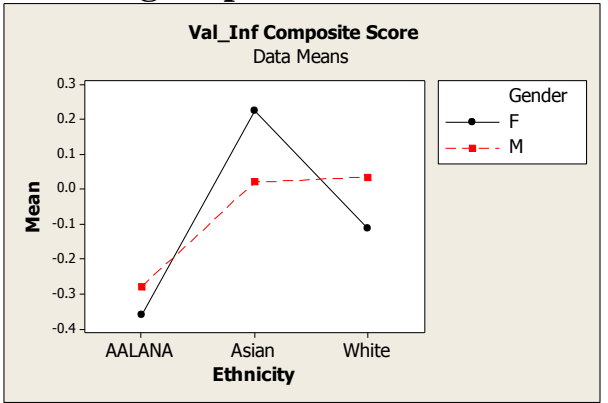

Figure 6. Department Climate Composite Score by Gender and Ethnicity (higher score $=$ more positive perception of department climate)

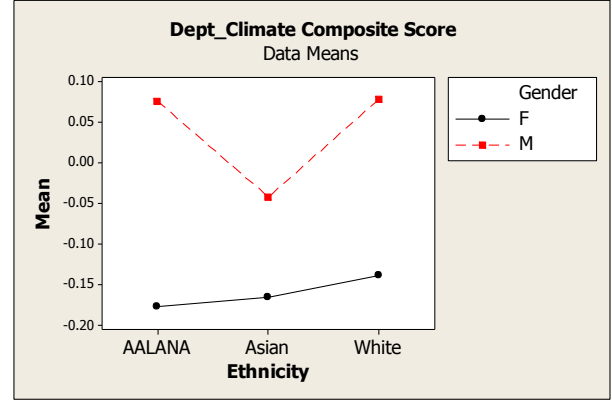

Figure 7. Work/Life Stress Composite Score by Gender and Ethnicity (higher score $=$ lower reported level of stress)

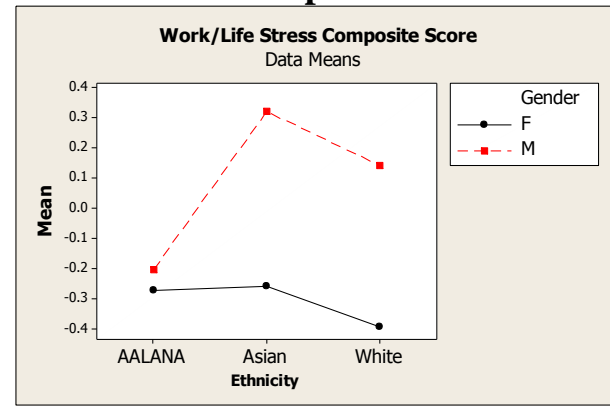


Composite scores for each measure were also examined by college and gender. Figures 8 - 10 show the distributions of composite scores, and Table 5 summarizes college-level average scores. The college identifiers include a generic numbering scheme and a STEM or non-STEM designation based on the predominant number of STEM or non-STEM programs within each college. Scores were analyzed using two-way ANOVA. No significant interaction effects were present. Composite scores of Value \& Influence, Department Climate, and Work/Life Stress varied by gender and by college as described below.

- Differences in mean Value \& Influence composite score are significant by Gender ( $\mathrm{p}<0.05$ ), but not by College as shown in Figure 8 and in Table 5. Specifically, once college has been accounted for, the mean for female respondents is significantly lower than the mean for male respondents (Table 5).

- Differences in mean Department Climate composite score are significant by Gender $(\mathrm{p}<0.01)$, and by College $(\mathrm{p}<0.01)$. Once college has been accounted for, the mean for female respondents is significantly lower than the mean for male respondents; once gender has been accounted for, the mean scores for the colleges are significantly different; see Figure 9 and in Table 5.

- Differences in mean Work/Life Stress composite score are significant by Gender $(\mathrm{p}<0.0001)$, but not by College. Specifically, once college has been accounted for the mean for female respondents is significantly lower than the mean for male respondents as shown in Table 5.

Figure 8. Value \& Influence Composite Score by College and Gender (higher score $=$ higher perceived value $\&$ influence)

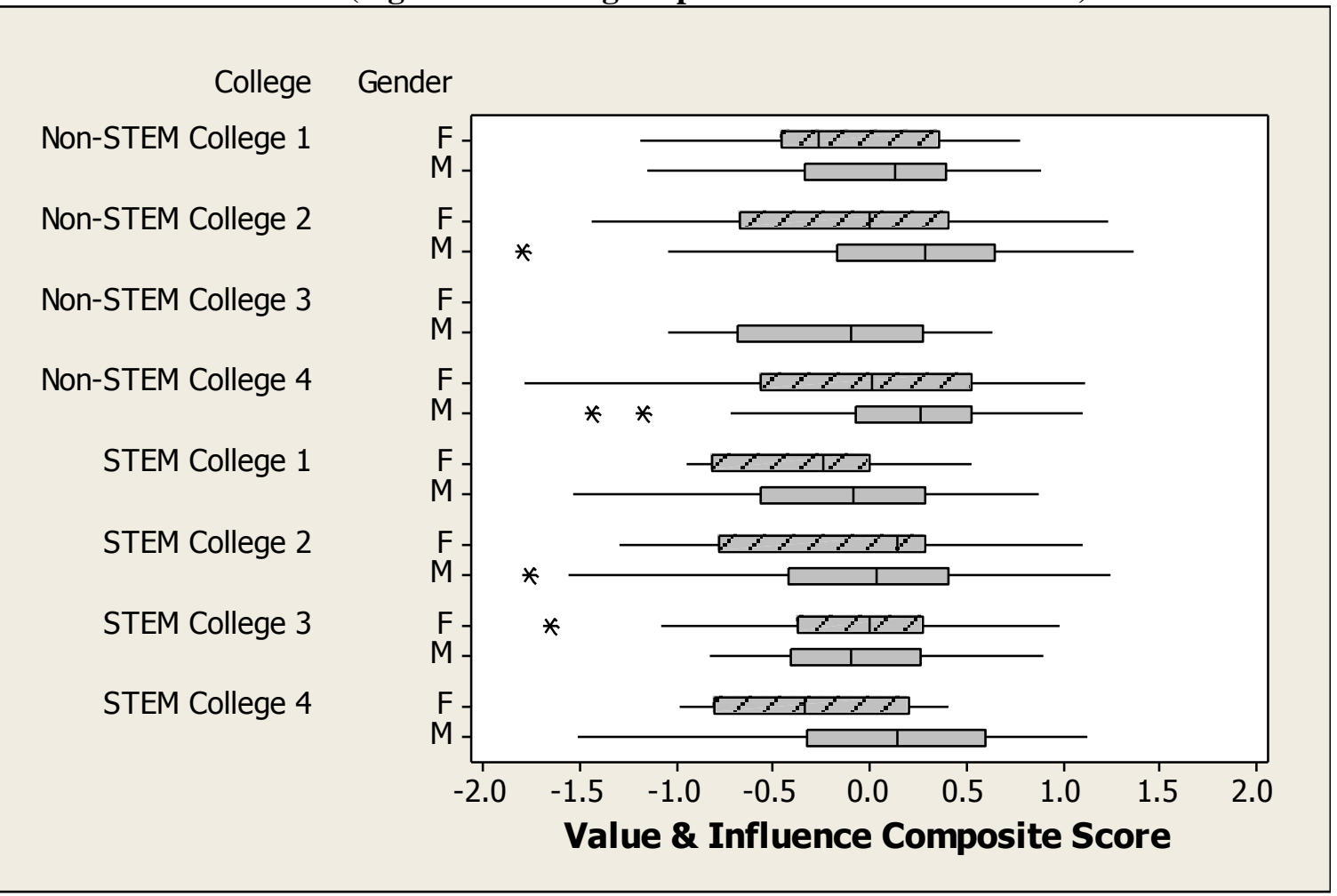


Figure 9. Department Climate Composite Score by College and Gender (higher score $=$ more positive perception of department climate)

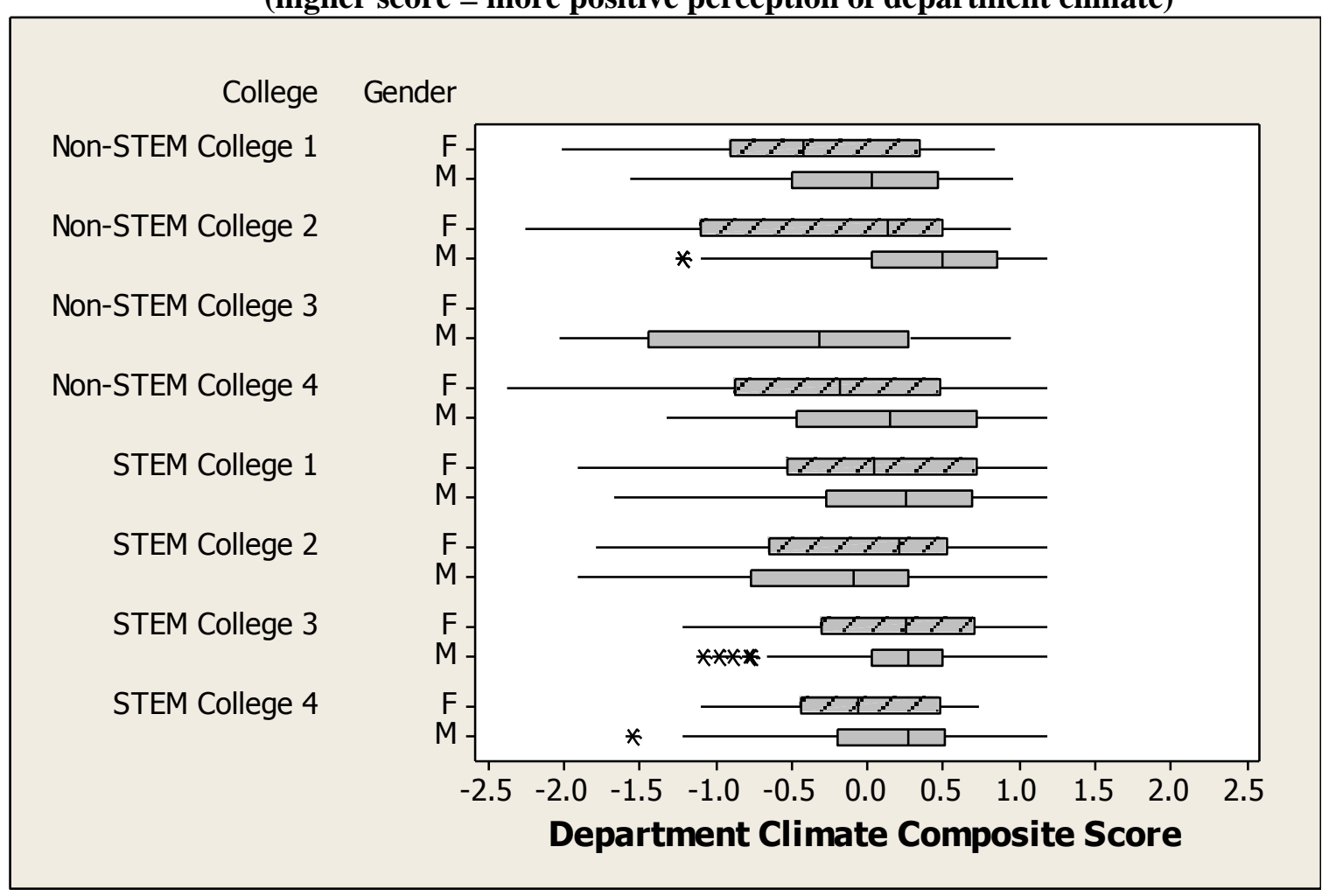

Figure 10. Work/Life Stress Composite Score by College and Gender (higher score $=$ lower reported level of stress)

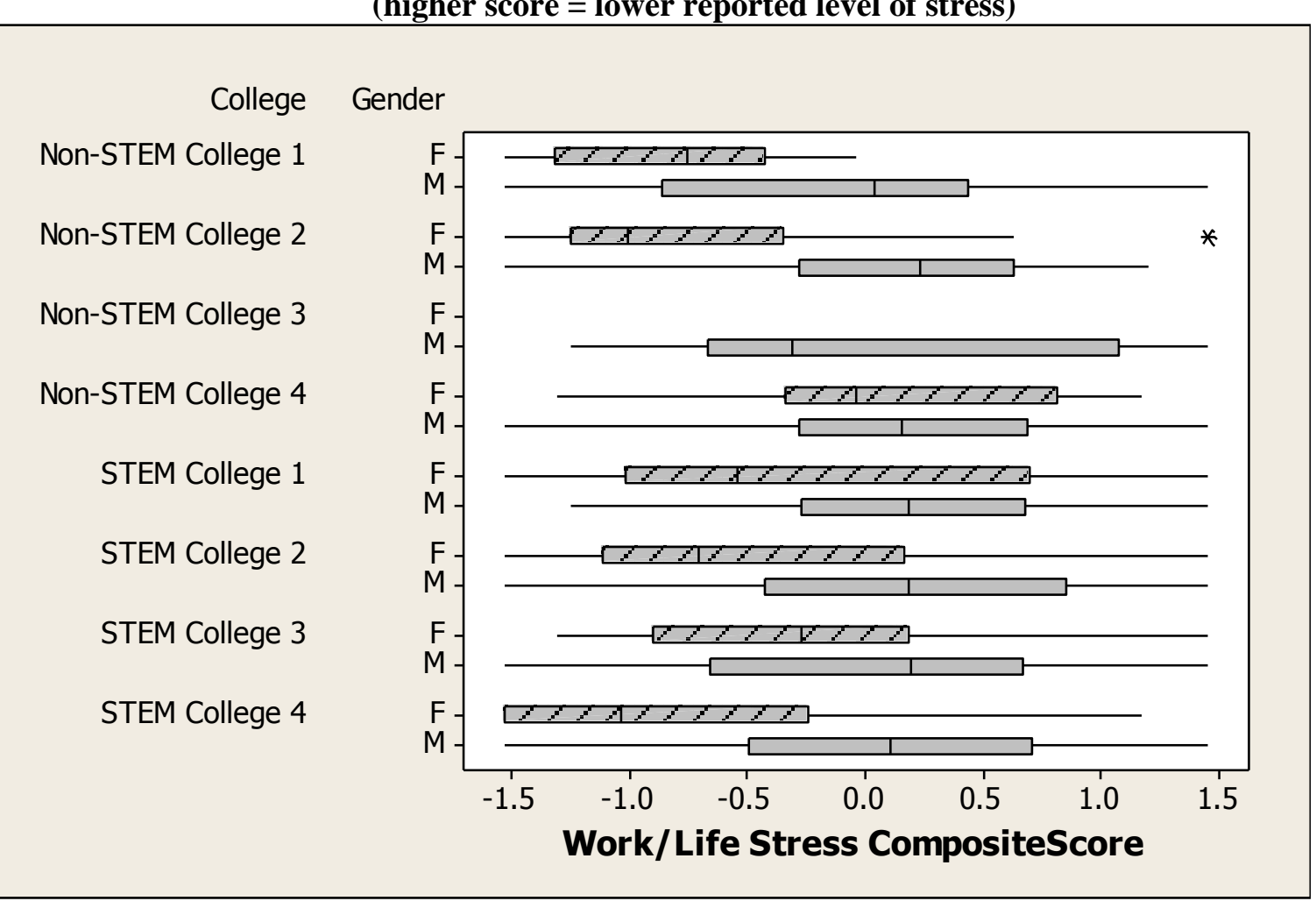


Table 5. Composite Scores by College and Gender

\begin{tabular}{|c|c|c|c|c|c|c|c|c|c|}
\cline { 2 - 9 } $\begin{array}{c}\text { Cell } \\
\text { Contents: } \\
\text { Mean }\end{array}$ & \multicolumn{3}{|c|}{\begin{tabular}{c} 
Value \& Influence \\
\cline { 2 - 9 }
\end{tabular}} & Femposite Score & \multicolumn{2}{c|}{$\begin{array}{c}\text { Department Climate } \\
\text { Composite Score }\end{array}$} & \multicolumn{3}{c|}{$\begin{array}{c}\text { Work/Life Stress } \\
\text { Composite Score }\end{array}$} \\
\hline $\begin{array}{c}\text { Non-STEM } \\
\text { College 1 }\end{array}$ & -0.093 & 0.031 & -0.124 & -0.345 & -0.052 & -0.293 & -0.814 & -0.025 & $-0.789 *$ \\
\hline $\begin{array}{c}\text { Non-STEM } \\
\text { College 2 }\end{array}$ & -0.094 & 0.183 & -0.277 & -0.235 & 0.346 & $-0.581 *$ & -0.697 & 0.104 & $-0.801 *$ \\
\hline $\begin{array}{c}\text { Non-STEM } \\
\text { College 3 }\end{array}$ & $* *$ & -0.164 & N/A & $* *$ & -0.552 & N/A & $* *$ & 0.067 & N/A \\
\hline $\begin{array}{c}\text { Non-STEM } \\
\text { College 4 }\end{array}$ & -0.052 & 0.173 & -0.225 & -0.244 & 0.129 & $-0.373 *$ & 0.118 & 0.108 & 0.010 \\
\hline $\begin{array}{c}\text { STEM } \\
\text { College 1 }\end{array}$ & -0.343 & -0.182 & -0.161 & -0.005 & 0.160 & -0.165 & -0.245 & 0.233 & -0.478 \\
\hline $\begin{array}{c}\text { STEM } \\
\text { College 2 }\end{array}$ & -0.153 & -0.040 & -0.113 & 0.014 & -0.155 & 0.169 & -0.386 & 0.152 & $-0.538 *$ \\
\hline $\begin{array}{c}\text { STEM } \\
\text { College 3 }\end{array}$ & -0.049 & -0.063 & 0.014 & 0.200 & 0.178 & 0.022 & -0.302 & 0.070 & -0.372 \\
\hline $\begin{array}{c}\text { STEM } \\
\text { College 4 }\end{array}$ & -0.310 & 0.106 & -0.416 & -0.040 & 0.195 & -0.235 & -0.660 & 0.154 & -0.814 \\
\hline
\end{tabular}

*Significant difference by gender

$* *$ Unable to report where $\mathrm{n}<5$ respondents

Examination of composite scores by gender within each college revealed a number of interesting results (see Table 5). Restricting to one college at a time drastically reduces the sample sizes, and makes it more difficult to achieve statistical significance. However, using two-sample t-tests for a college's scores, it was found that,

- With regard to the Department Climate Composite Score, two colleges had significant differences by gender.

$\circ$ Within the non-STEM Colleges 2 and 4, female faculty report a less positive view of department climate than male faculty ( $p<0.01$ and $p<0.05$, respectively).

Recall that across all RIT, there is a significant difference by gender in regards to view of department climate $(\mathrm{p}<0.01)$.

- With regard to the Work/Life Stress Composite Score, three colleges had significant differences by gender.

- Within the non-STEM Colleges 1 and 2 and within STEM College 2, female faculty report lower responses which corresponds to more stress $(\mathrm{p}<0.05, \mathrm{p}<0.01$, and $\mathrm{p}<0.05$, respectively). Recall that there is a significant difference by gender in reported work/life stress across all colleges at RIT ( $p<0.0001)$.

Gender differences for the Value \& Influence and Work/Life Stress composite scores were largest for respondents from the STEM College 4. However due to small sample size, statistical significant is not achieved.

To summarize, gender differences in Value \& Influence and Work/Life Stress are not college specific, but are pervasive across the institute. Gender differences in Department Climate, however, differ significantly across the colleges.

Results have been prepared at the department level for dissemination to department heads. Documents include an explanation of how the composite scores are computed, and a set of 
graphical displays providing results by gender at the institute level (as shown above), results by gender for the department's college, and scores at the department level are not split by gender due to the small sample sizes. In addition, the distributions of average department scores by departments are provided. See Figures 11 - 13. Each dot represents the average for a department at RIT with $\mathrm{n} \geq 5$ respondents. With this information in hand, department heads will be informed regarding their departmental faculty's overall responses to the three measures and how these responses compare with other departments within their college and with other STEM and nonSTEM departments outside of their college. Each dot represents a department. No identifying information is provided, other than whether the department is from a STEM or non-STEM college. The distributions, though not exactly "normal" (or bell-shaped), do not deviate significantly from normality.

Figure 11. Department Averages for the Value \& Influence Composite Score

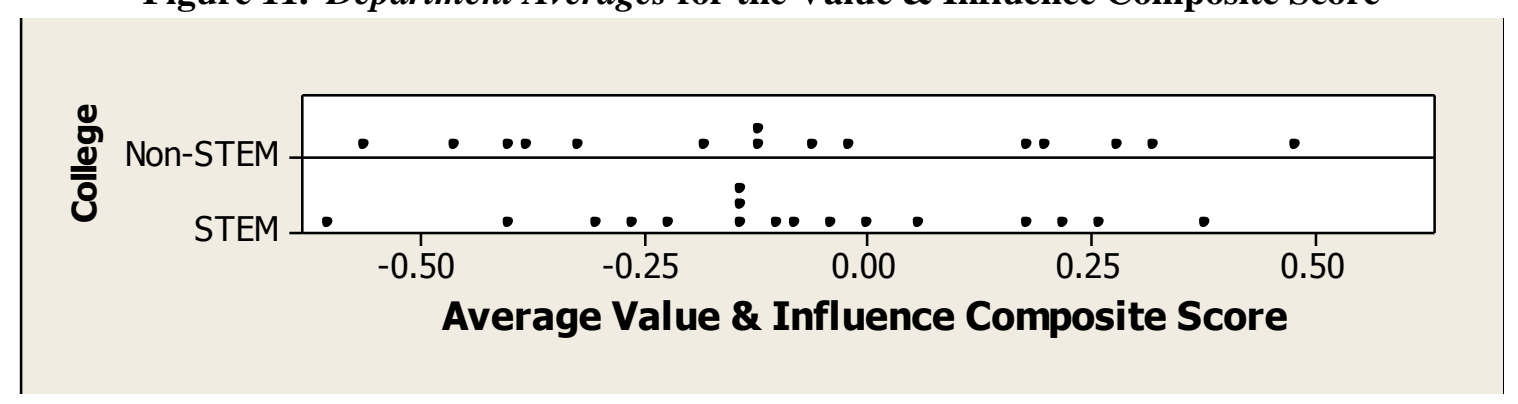

Figure 12. Department Averages for the Department Climate Composite Score

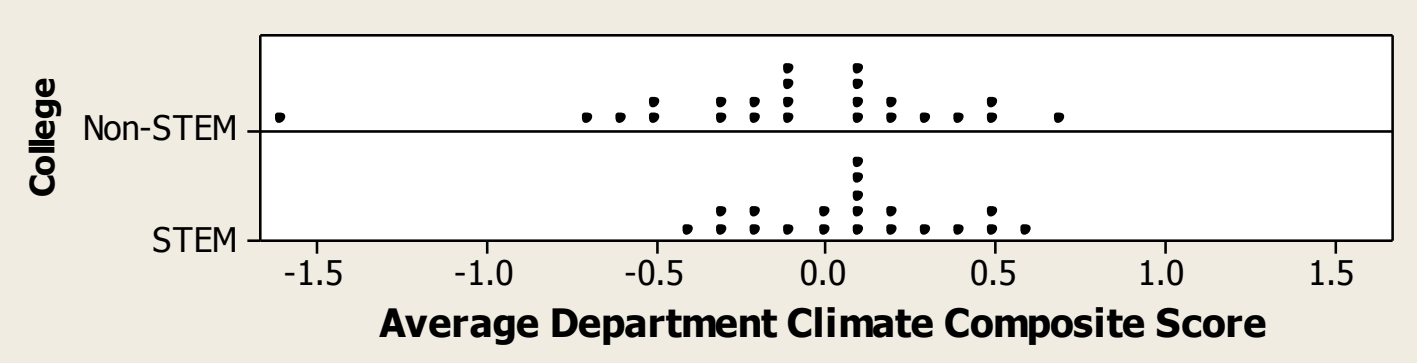

Figure 13. Department Averages for the Work/Life Stress Composite Score

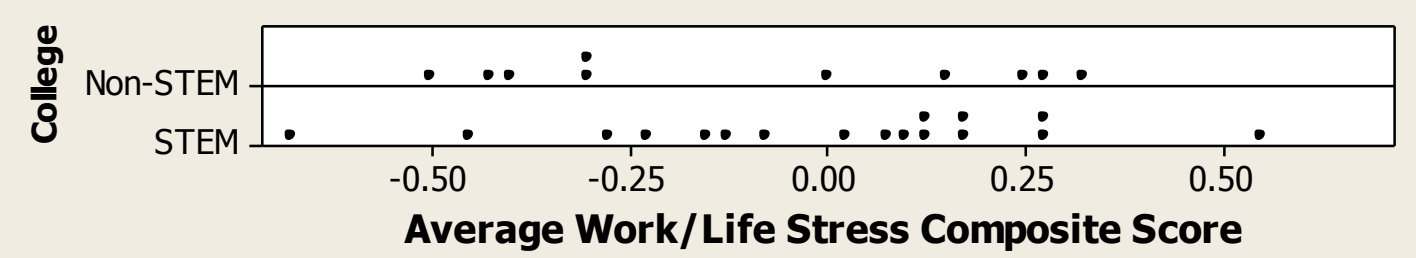

\section{Institutional Transformation Strategy}

An institutional transformation strategy has been created for RIT based on answers to research questions explored in this paper and other related survey questions which led to the identification of career barriers for current women faculty in regards to recruitment and advancement. The results of data analysis were crucial in identifying key areas of focus for the institutional transformation strategy. The specific goals of the transformation strategy are to: 
1. Increase the recruitment, retention, and advancement of women STEM/SBS faculty from diverse ethnic, social, and cultural backgrounds.

2. Increase the representation of women at senior faculty and leadership ranks.

3. Advance the careers of women STEM/SBS faculty through improvements in social networking behaviors, increasing their ability to access social resources to accomplish career objectives.

4. Institutionalize interventions that support change across the university in line with the project goals.

Goals will be accomplished by refining and strengthening targeted institutional structures while creating new supporting practices; improving the quality of faculty work life; shaping the political frameworks that impact representation and advancement of women faculty; enhancing the working environment; and establishing a sustainable RIT network that is inclusive of all faculty members in supporting their career goals.

\section{Conclusion}

The ADVANCE IT-Catalyst project, "Establishing the Foundation for Future Organizational Reform and Transformation at Rochester Institute of Technology" identified barriers to the recruitment and advancement of women STEM faculty involving career navigation, climate, and flexibility/options for managing the work/life balance. From faculty climate survey data, composite scores were created to capture faculty perceptions of value and influence, department climate, and work/life balance. Exploration of faculty satisfaction indicates that overall satisfaction for men and women seems to be tied to faculty perception of value and influence, and to a lesser extent to one's view of the department climate. Faculty perception of value and influence is significantly lower for female faculty than male faculty, and significantly lower for AALANA faculty than for White faculty. Faculty perception of department climate and work/life stress differ significantly by gender, but not by ethnicity, with female faculty having a less positive view of department climate, and higher reported levels of stress. Lastly, gender differences in value \& influence and work/life stress are found across the institute, but gender differences in one's view of the department climate, however, are significantly different across the colleges. Reporting composite score results by college and department, and by gender and ethnicity, opens the door for constructive conversation about climate with department heads and administrators.

A wide-scale dissemination effort is underway to educate interested members of the university community and initiate and encourage productive dialogue regarding issues identified during the course of this study. Simultaneously, policy and administrative practice changes are ongoing to address tenure-clock extension; faculty exit interview protocol; dual-career hire practices; and triennial faculty climate survey administration. In addition, a comprehensive institutional transformation strategy has been created. The strategy addresses identified issues and is an effort across RIT's nine colleges, all of which include STEM and/or social and behavioral science (SBS) disciplines. The project's goal is to increase the representation and advancement of women STEM/SBS faculty, widely represented across ethnic, social, and cultural backgrounds, by removing barriers to resources that support career success and creating new interventions and resources. Implementation of this strategy is being staged and the speed and extent of roll-out depends significantly on availability of resources. 


\section{Acknowledgement}

Support for this research was provided by the National Science Foundation ADVANCE Institutional Transformation Catalyst (IT-Catalyst) program under Award No. 0811076. Any opinions, findings, and conclusions or recommendations expressed in this material are those of the author(s) and do not necessarily reflect the views of the National Science Foundation.

\section{References}

1 Bailey, M., Marchetti, C., DeBartolo, E., Mason, S., Valentine, M., Baum, S., Mozrall, J., \& Williams, G. (2011). Establishing the Foundation for Future Organizational Reform and Transformation at a Large Private University to Expand the Representation of Women Faculty, Proc. 2011 American Society for Engineering Education Annual Conference \& Exposition, Vancouver, BC, June. Accessed Nov. 3, 2011 from http://nsfadvance.rit.edu/publications-and-documents.

2 National Science Foundation, Division of Science Resources Statistics. 2011. Women, Minorities, and Persons with Disabilities in Science and Engineering: 2011. Special Report NSF 11-309. Arlington, VA. Available at http://www.nsf.gov/statistics/wmpd/, downloaded Nov 4, 2011. TABLE 7-2. S\&E doctoral degrees awarded to women, by field: 2000-08.

3 National Science Foundation, $S \& E$ Doctoral Degrees Awarded to Women, by Field: 2000 08, Table F-2, Women, Minorities, and Persons with Disabilities in Science and Engineering. Available from http://www.nsf.gov/statistics/wmpd/tables.cfm, downloaded 25 February 2011.

4 Stepina, N. \& Campbell, J., "Longitudinal Tenure and Attrition Rate Study in the State University System of Florida", Annual Forum of the Association of Institutional Research, Kansas City, MO, May, 1987. Available online at http://www.eric.gov/PDFS/ED293438.pdf

5 Honeyman, D. S. \& Summers, S. R., "Faculty Turnover: An Analysis by Rank, Gender, Ethnicity, and Reason". Proceedings of the National Conference on Successful College Teaching, February, 1994. Available online at http://eric.ed.gov/PDFS/ED390455.pdf

6 August, L. "It Isn't Over: The Continuing Under-Representation of Female Faculty", Presented at the Association for Institutional Research, Chicago, May, 2006. Available online at http://www.cew.umich.edu/sites/default/files/augustfemrep06 0.pdf

7 Penn State Faculty Exit Study (2008)

8 Cornell Faculty Work Life Survey (2006), Understanding Faculty Satisfaction

9 Trower, C. A., "Senior Faculty Satisfaction: Perceptions of Associate and Full Professors at Seven Public Research Universities" Advancing Higher Education, June 2011.

10 Trower, C. A. \& Bleak, J. L. (2004) "Study of New Scholars" Gender: Statistical Report [Universities]. Cambridge, MA: Harvard Graduate School of Education.

11 Russo, G. (2010), "For Love or Money", Nature, 465, 1104-1107.

12 Trower, C. A., "Senior Faculty Vitality" Advancing Higher Education, June 2011.

13 ADVANCE University of Michigan "Assessing the Academic Work Environment for Scientists and Engineers (2002)". Available from http://sitemaker.umich.edu/advance/campus-wide_climate_for_faculty,_downloaded 28 February 2011.

14 ADVANCE University of Wisconsin-Madison "Survey of Faculty Worklife (2006)". Available from http://wiseli.engr.wisc.edu/advance.php, downloaded 28 February 2011.

15 Cornell University Survey Research Institute. http://sri.cornell.edu

16 Harvard University Faculty Climate Survey 2006/7 Report, prepared by Institutional research \& Faculty Development and Diversity. 
17 Diana Bilimoria, Susan R. Perry, Xiangfen Liang, Patricia Higgins, Eleanor P. Stoller, and Cyrus C. Taylor, "How Do Male and Female Faculty Members Construct Job Satisfaction?" presented at the 2005 NSF-ADVANCE Meeting in Washington, D.C. Available from http://www.case.edu/admin/aces/resources.htm?nw view=1294780243\&, downloaded 25 February 2011. 